\title{
DEVELOPMENT STUDIES RESEARCH 1975-2014 IN ACADEMIC JOURNAL ARTICLES: THE END OF ECONOMICS?
}

\section{Investigación sobre estudios de desarrollo 1975-2014 en artículos de revistas académicas: ¿el fin de la economía?}

\author{
Mike Thelwall and Sam Thelwall
}
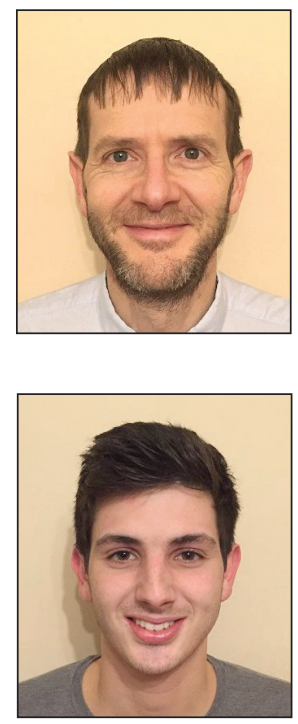

Mike Thelwall is the head of the Statistical Cybermetrics Research Group at the University of Wolverhampton, UK. He has developed a wide range of software for gathering and analysing web data, including hyperlink analysis, sentiment analysis and content analysis for Twitter, YouTube, MySpace, blogs and the Web in general.

http://orcid.org/0000-0001-6065-205X

Statistical Cybermetrics Research Group, School of Mathematics and Computer Science, University of Wolverhampton Wulfruna Street, Wolverhampton WV1 1LY, United Kingdom m.thelwall@wlv.ac.uk

Sam Thelwall is an undergraduate studying the history of economics in the School of Arts, Languages and Cultures, University of Manchester. http://orcid.org/0000-0002-6447-4497

University of Manchester, School of Arts, Languages and Cultures Manchester, United Kingdom samuel.thelwall@student.manchester.ac.uk

\begin{abstract}
The field of development studies analyses causes and potential solutions for global poverty and inequality. Since the Second World War there have been major changes in theories about the root causes of global poverty and the strategies necessary to tackle it. This article views the history of development studies from the perspective of the role of economics during 19752014. A topic modelling analysis of published journal articles from Scopus suggests that there has been a relative decline in research that focuses on economics, and particularly for research concerned with firms and growth. In parallel, the analysis suggests that there has been a relatively slow increase in interest in the environment, a lack of scholarly interest in BRICS and dependency theory, and a relatively homogeneous treatment of gender issues.
\end{abstract}

\section{Keywords}

Development studies; Trends analysis; Topic models; Scientometrics; Bibliometrics; Economics.

\section{Resumen}

En los estudios sobre desarrollo se analizan las causas y las posibles soluciones para la pobreza y la desigualdad globales. Desde la Segunda Guerra Mundial se han producido cambios importantes en las teorías sobre las causas de la pobreza mundial y las estrategias necesarias para hacerle frente. En este artículo se revisan los estudios de desarrollo publicados en el período 1975-2014 desde la perspectiva del papel jugado por la economía. Un análisis de los temas de los artículos publicados en revistas indexadas en Scopus sugiere que ha habido una disminución relativa de la investigación centrada en la economía, y en particular en la investigación sobre empresas y crecimiento. Paralelamente, el análisis sugiere que se ha producido un lento aumento en el interés por el medio ambiente, falta de interés del mundo académico por los países BRICS y la teoría de la dependencia, y un tratamiento bastante homogéneo de las cuestiones de género.

\section{Palabras clave}

Estudios sobre desarrollo; Análisis de tendencias; Modelos temáticos; Cienciometría; Bibliometría; Ciencias económicas; Economía. 
Thelwall, Mike; Thelwall, Sam (2016). "Development studies research 1975-2014 in academic journal articles: The end of economics?". El profesional de la información, v. 25, n. 1, pp. 47-58.

http://dx.doi.org/10.3145/epi.2016.ene.06

\section{Introduction}

The field of development studies is concerned with "the existence and seemingly inexorable deepening of global poverty and inequality" (Potter, 2014a, p. 17), although there are disagreements about the precise nature or core goals of the field (Schuurman, 2009). Three alternative conceptions of development coexist: development as the long term progress of a nation towards a highly productive economy; development in the sense of short to medium term progress of a nation or region towards specific goals that improve the human condition; and development as a Western discourse to justify its actions (Sumner; Tribe, 2008b). The second of these seems to be currently the most widespread but the development studies field is concerned with all of them. Development studies grew from the late 1940s (Khoo, 2015) and then emerged as a discipline in the 1960s with the establishment of research institutes in the UK, followed by courses and journals (Potter, 2014a; Sumner; Tribe, 2008a). It was a deliberately multidisciplinary combination of economics, agricultural science, sociology and other fields to promote positive changes in the human condition in economically poor areas of the world (Sumner; Tribe, 2008a). Although a new discipline, it had some personnel and ideological continuity with previous development initiatives and related colonially-focused research (Craggs, 2014).

\section{The importance and relevance of econo- mic development seem to have declined substantially for a number of different reasons}

The concept of economic development has its origins mainly in the Marxist theory of societal progress through different economic stages but after the Second World War the term was increasingly used by non-Marxists to mean economic growth in general (Arndt, 1981). The importance and relevance of economic development seem to have declined substantially, however, for a number of different reasons. First, a recognition that economic growth does not automatically lead to better outcomes for the majority of the population has led to a new interest in human development. Second, the rise in importance of the environment gives a perspective from which economic growth is not necessarily a good in itself and can also provide its own problems, especially for the poor. Third, the increasingly globalised economy has undermined the relevancy of economic development strategies for individual countries. Given these changes, has the overall influence of economics within development studies declined or has it just changed focus? This is an important issue to inform the education and recruitment of future development professionals as well as for current researchers to understand the current status of their field. This question is difficult to answer clearly, however, despite several published histories of the field, because development studies is a multidisciplinary, practice-oriented field that has continued to evolve substantially over time. An information science approach that quantitatively analyses the published development studies literature may help to shed light on the evolution of the field by interpreting the available data from a different perspective.

\section{Post development theory argued that standard Western conceptions of deve- lopment were outdated}

This article investigates the role of economics in development studies in recent years and as well as the wider history of development studies. The approach used is a text analysis of published research 1975-2014 in academic journal articles. It uses topic modelling to identify trends in the topics discussed so that their evolution over time can be analysed. Economics here is broadly defined to encompass both macroeconomics (the economy as a whole) and microeconomics (the economic behaviour of individuals and organisations), but this article is concerned with contributions from economics as a discipline, rather than contributions from other disciplines (e.g., agriculture) that impact on the economy (e.g., by making farmers more productive).

\section{A brief history of development studies and issues}

This section gives the necessary background to set the context for the topic modelling results. The current concept of development originates from the 1949 inaugural speech of President Harry S. Truman (Rist, 2014; Schuurman, 2014), which introduced the term 'underdevelopment' for nations, meaning economically backwards. It also argued for the need to support international development, focused almost exclusively on facilitating economic growth. Growth theory, which dominated post-war development studies, derived from Keynes (Knutsson, 2009; Preston, 1996) and was mainly concerned with economic growth, state planning and international aid (Preston, 1996).

During the 1950s, institutional and cultural factors that affect economic growth were analysed and became widely known as modernisation theory (Lewis, 1978; Preston, 1996). Modernization theory culminated in the influential book The stages of economic growth: A non-communist manifesto (Rostow, 1960). This book utilised an aviation metaphor to illustrate a 5 stage path on the road to an 'age of mass high consumption' with a focus on high levels of investment with heavy state involvement. 
The 1960s was the UN's Decade of development, again focusing on economic development. The UN argued that all nations should aim to achieve a minimum of $5 \%$ annual growth in national income by the end of the decade (United Nations, 1961). Thus, the 1960 s continued to equate economic growth with development, although the importance of non-economic issues was also acknowledged to some extent (Jolly, 2005).

The field of development diversified in the 1970s as two new theories emerged which challenged the conventional wisdom of purely using the economy as a catalyst for development and of ignoring non-economic development. The first of these, dependency theory, had roots in the Latin America Structuralism School, which theorised that underdevelopment in countries stemmed from the exploitation of their resources by the more developed countries (Willis, 2011). They argued for a policy of self-reliance from the globalised world in order to have protected and sustained industrialisation (Rist, 2014). This theory deviates from growth and modernisation theory in terms of the strategies recommended to achieve economic growth. Moreover, dependency theory argued that the West were often the economic beneficiaries of their own development interventions, which did little to alleviate inequality and poverty (Potter; Conway, 2011).

The second major theory emerged with publication of the Dag Hammarskjöld report What now: Another development (United Nations, 1975). This redefined the term development, arguing that it can no longer be understood as a purely economic process with a universal formula but that it should be geared to satisfying the basic needs of the poorest sections of society through their own forces (Rist, 2014). These ideas focus on a more needs orientated view for different geographic areas in contrast to aiming for an age of universal high mass consumption. In particular, the report's basic needs approach was adopted by various UN agencies and the World Bank, who began to include social indicators into traditional growth models (Knutsson, 2009). The inclusion of social indicators enshrined the importance of factors other than economic growth and the another development report inclusion of the poorest sections of society gave rise to ethnic, gender, ecological concerns being included within development studies.

In the 1980s, the post-war Keynesian consensus about the importance of state spending was replaced with a widespread adherence to monetarism (i.e., controlling the money supply) in the Western world (Kaldor, 1985). With this change, development economics shifted towards away from the state towards free-market solutions, such as international trade and direct foreign investment (Preston, 1996). This offered a different academic apparatus to achieve economic growth in the developing world. This approach was challenged by the 1987 Brundtland Commission report, which argued for sustainable development (World Commission on Environment and Development, 1987). This brought environmentalism into the forefront of development studies (Redclift, 2014).

Post development theory argued that standard Western conceptions of development were outdated (Escobar, 1992; Nustad, 2001; Sidaway, 2014). It argued that Western deve- lopment efforts were based on false notions of colonial superiority and geopolitical concerns and offered a lack of understanding of the diverse cultures of the world (Knutsson, 2009). Post development theories in the 1980 s emphasised environmental issues along with respect for local communities (Briggs, 2014; Mohan, 2014).

From the 1980s to the 1990s, the issue of economic globalization became important within development studies because of the consequent decline in the influence of the nation state (Herod, 2014; McMichael, 2012; Schuurman, 2014). This seems to have led to a decrease in importance for economic theory and an increased focus on other issues. Environmental concerns became foregrounded with the UN-organised Rio Summit of 1992, and have continued to grow in importance (Rist, 2014), especially through the concept of sustainable development (Redclift, 2014). The new institutional economics (the need for effective development institutions) is an economic theory from the 1970s that also became influential in the 1990s (Lepenies, 2014), and post-development ideas started to get substantial discussion, arguing that standard Western conceptions of development were outdated (Escobar, 1992; Nustad, 2001; Sidaway, 2014). From the middle of the 1990s, the concept of social capital, relating to the importance of social networks for mobilising resources, gained substantial attention in society and began to influence development thinking and policy (Bebbington; Foo, 2014). The importance of gender issues and empowering women also increased steadily from the 1970s (Pearson, 2005) with the UN Decade for women 1975-1985 and was firmly in the mainstream in 1995 with the UNDP's Gender-related development index (GDI) and Gender empowerment measure (GEM).

In the 1990s, the concept of human development was recognised, with the conditions of human life becoming part of an understanding of development

In the 1990s, the concept of human development was recognised, with the conditions of human life becoming part of an understanding of development. Amartya Sen's highly influential Development as freedom emphasised improving living conditions, including political freedoms, social opportunities, government transparency and security (Sen, 1999; see also: Sen, 1983). These ideas were formalised and tracked with the Human development indicator (HDI) and the commissioning of periodic Human development reports by the UN (Desai; Potter, 2014; Thirlwall, 2011). The HDI includes a variety of social factors, such as life expectancy, literacy rates and mean years of schooling and the development reports focus upon the wider lifestyle of the population (UN Human development report, 1999). This institutionalisation of social factors into measurements of development represents a clear move within development studies away from pure economic growth towards a balance with a variety of conditions for humanity. This led to many development issues being framed in terms of human rights or freedoms (Elliott, 2014). 
In 2000, a set of eight millennium development goals (MDGs) with specific measurable targets were approved by the United Nations (UN) and were subsequently adopted by 190 countries. This was a milestone as an apparent consensus on the importance of human development rather than economic development (Rist, 2014). The growth of globalisation seems to have increased the relevance of social protection (Standing, 2010; see also: Bindura-Mutangadura, 2001 ) in the 2000s, despite the term being old and social protection issues having been widely discussed with different terminology. One article suggested that key new issues for the 2000s included the economic rise of China and India, a loss of confidence in neoliberal economic policies, increasing inequality, cultural and religious conflicts, climate change, energy, the influence of outside donors in developing countries, the capacity within countries and development NGOs to make a difference, and migration (Haddad, 2007). Another topical issue was the rapid economic development of the BRICS (Brazil, Russia, India, China, South Africa) nations, which was first noticed in 2003 without South Africa, and the grouping was formalised through inter-governmental meetings from 2009 (BRIC) and 2011 (BRICS) (Cassiolato, 2014). Development studies also seems to have been affected by the world economic crisis of 2007-2008, which may have caused a re-appraisal of previously dominant economic strategies (Schuurman, 2009). One outcome of this was a shift towards a postmodern focus on promoting diverse rather than universal solutions (Schuurman, 2014), perhaps undermining the role of academic theory.

The concept of the Third World, dating from the cold war, was replaced by the global South in the 1980s

In parallel with the above there have been changes in terminology and perspectives. In particular, the concept of the Third World, dating from the cold war, was replaced by the global South in the 1980s, reflecting a belief that the primary split in world development terms was binary rather than trinary (Dodds, 2014). There has also been a move to describe the least developed nations as developing or poor instead of undeveloped (Desai; Potter, 2014). FinaIly, although new theories and ideas have been introduced over time, the different underlying aims of researchers have allowed older ideas and theories to continue alongside the new ones (Potter, 2014b).

In summary, development studies has diversified greatly since Truman's Four point speech. The academic discourse within the field has moved from focusing on Keynesian economic growth models to expressing wider concerns for the environment, gender, ethnicity and social welfare. Nevertheless, although new theories and ideas have been introduced over time, the different underlying aims of researchers have allowed older ideas and theories to continue in parallel (Potter, 2014b). Development studies seems to have focused on policy-relevant issues, however. For example, the Green Revolution of agricultural improvements in the South from the 1940 s to the 1960 s that has greatly re- duced food scarcity (Conway, 1998) appears to have generated little published development studies research.

\section{Quantitative text-based literature analysis methods}

A simple method to identify changes in topics over time is to track all words used in all articles to discover those that tend to occur more often in later years than in earlier years, or vice versa (Thelwall; Maflahi, 2015; see also a word frequency analysis of six British white papers on aid: Alfini; Chambers, 2010). This has the limitation that a topic may be discussed with phrases rather than individual words, and that a concept may be discussed with many different terms. Within development studies, different terms are used to describe the same basic issue over time (Cornwall, 2010) and so tracking individual words may reflect changing jargons rather than changing issues.

\section{Patterns of co-occurrence of terms can be used instead of tracking individual words}

Patterns of co-occurrence of terms can be used instead of tracking individual words. With co-word analysis, terms or phrases that frequently occur together within academic publications (or their titles, abstracts and/or keywords) may point to important concepts that can be tracked over time through the frequency of occurrence of the term pairs (Ding; Chowdhury; Foo, 2001; He, 1999). Like most wordfrequency approaches, however, it has the limitation that it may reflect changes in terminology rather than changes in topic (e.g., Leydesdorff, 1997).

Topic modelling (Blei; Ng; Jordan, 2003) circumvents the problems of analyses based on individual words in a more powerful way by identifying collections of terms that tend to co-occur within documents. In contrast to the methods described above, it is a statistical dimension reduction technique that attempts to condense a collection of documents into the sum of their key topics. It works by first representing each article as a list of words and phrases and then attempting to compress this list into the main underlying topics using latent Dirichlet allocation (Wallach, 2006). This method may be able to identify topics that are common to documents even if they are discussed using different terms, as long as pairs of documents discussing the topic tend to have at least some terms in common. For example, if most articles discussing basic needs tend to either use the phrase basic needs or a few closely related terms, such as food, water, and shelter, then the latent Dirichlet allocation algorithm may be able to extract basic needs as a topic.

If the topic modelling process is effective then each collection of terms extracted represents a topic that is discussed in some documents but not in others. Each document can then be modelled as a weighted sum of the different topics. For example, document 1 may be 0.5 times topic 1 plus 0.5 times topic 4 . The evolution of a topic over time can then be 
tracked by assessing the average contribution of each topic to documents in each year (Yan, 2015). Although one study has used topic models to identify changes in topics within a field over time (Yan, 2015), it analysed library and information science rather than development studies.

\section{Research questions}

The primary goal of this article is to discover what has happened to economics in published research within development studies over the past 40 years. This time period was chosen as a pragmatic step due to the availability of data for relevant journals. The secondary goal is to ascertain which method is the best, to check whether any apparently reasonable method would give misleading information, and to assess how sensitive the results are to the method used.

RQ1: Have all economic-related issues have declined in importance during the period 1975-2014?

RQ2: Which issues have emerged to replace or challenge economics within development studies?

Topic modelling circumvents the problems of analyses based on individual words in a more powerful way by identifying collections of terms that tend to co-occur within documents

\section{Methods}

The overall approach was to identify the main topics within published development studies research, to track any changes in their contribution over time, and to analyse them for the role of economics.

The first step was to identify relevant research published during 1975-2014. Although important development studies research is published in monographs, edited volumes and NGO grey literature, only journal articles were considered because these form a relatively uniform data source and should reflect to some extent discussions that occur in other formats. Nevertheless, this approach is likely to obscure issues that are mainly discussed in monographs and edited volumes, perhaps including ethics, race and gender. Articles were selected by journal rather than through citation-based or text-based clustering approaches (see: Braam; Moed; Van Raan, 1991) because any selection method based on individual articles is likely to influence the topics represented within the eventual sample in a non-transparent way. Hence, a set of core journals was identified so that all of their articles could be included. Scopus was chosen as the source of data because it is more comprehensive than the main alternative, the Web of Science.

To identify the core development studies journals, the 55 Web of Science Planning; Development journals were compared with the 227 journals classified as Development within Scopus, whether or not they were also classified as within another discipline, and the 45 journals classified by Science metrix as Development Studies. From this combined set, 30 journals were selected that appeared to be primarily focused on development issues (rather than planning), had English titles and abstracts, and had been published and continually indexed by Scopus for at least 15 years (see the Appendix). Most journals in the final list focused on one aspect of development, such as Africa, gender, or sustainability, rather than development as a whole. This introduces the possibility that changes in topic may occur due to the introduction of a specialist journal or its expansion. Nevertheless, the existence of specialist journals is also important recognition that the specialist aspect is important for the field and so their exclusion could also give misleading results, especially if they are successful and attract most articles that are relevant to their specialism.

Article information was extracted from Scopus for the selected journals, after excluding all documents that were not standard articles, such as reviews and editorials, as well as all articles lacking an abstract. Abstracts were processed to remove copyright statements and standard structured abstract headings. Each article was represented by its title, abstract and keywords (if any) merged into a single text. This approach was used both to give a fuller document representation than the title alone and because topic modeIling (see below) works better on longer documents (Tang; Meng; Nguyen; Mei; Zhang, 2014) (see Appendix, table 2). All articles from the selected journals were extracted from Scopus, including those before 1975 and after 2014 in order to give more data to build the topic models.

For this study the Mallet (McCallum, 2002) topic modelling software (mallet.cs.umass.edu) was used. Although there are many alternative topic modelling programs, Mallet is the most popular. Since all the programs use the same broad approach it seems unlikely that the results would be substantially different with another program. Topics can be extracted either on the basis of the individual words or bigrams (i.e., pairs of consecutive words) in a text. The bigram approach is more powerful because it can detect short phrases, such as 'environmental planning', with a meaning differing from the individual words and so this was used as the default setting. The alternative individual words (unigrams) approach was also used with 100 topics to crosscheck the results. Simple keyword counting was also used for crosschecking the results since the statistical modelling approach may sometimes generate anomalies.

\section{Scopus was chosen as the source of data because it is more comprehensive than the main alternative, the Web of Science}

The most suitable number of topics to identify is unknown in advance. Although there are statistical methods to automatically identify suitable numbers of topics (Griffiths; Steyvers, 2004), it is not clear that they are suitable for the task of tracking changes in topics over time. Hence, different numbers of topics were tried: 10,50 and 100 . The lowest number may reveal very broad trends whereas the largest may reveal much more specific trends. 


\section{Results and discussion}

The discussion is based upon the ten topics method but draws upon the data from 50 and 100 topics to give more depth to the results, when appropriate. The topic model with ten topics preselected produced ten reasonably coherent topics (table 1). Some of these topics increased over time (for example, environment and sustainability), some decreased over time (for example, economic growth and trade), and some stayed approximately constant (for example, politics, state and war). Despite these changes, no topics have disappeared. Hence, the thesis that established theories coexist with newer ones (Potter, 2014b) may also be true for broad research issues.

\section{The top ten topics}

The overall trend for the ten topics has been convergence, with all making similar contributions in recent years even though some were initially dominant and others almost non-existent at the start of the period (figure 1). This suggests that the main broad issues of 40 years ago are still actively researched today but have been joined by a number of new issues. The 50 topic model also did not identify any topics that had initially been strong but that has effectively disappeared in the last decade. The closest topics were firms (industry firms export industrial technology manufacturing productivity production technological industries firm exports innovation paper countries sector level trade developing) and economic models (model economy welfare equilibrium paper effects general price goods costs optimal cost policy trade models sector demand show analysis), both with contributions that declined by $60 \%$ from 0.05 per article in 1975-1984 to 0.02 per article in 2005-2014. The 100 topic also includes two topics that shrunk in contribution but that had not disappeared: economic models (model economy welfare equilibrium paper general models effects optimal dynamic policy sector show simple shown endogenous results consumption result) and class relations (class colonial agrarian peasant capitalist production capitalism author relations accumulation historical state century peasants british history social economy revolution), both declining by $66 \%$ from 0.03 per article in $1975-1984$ to 0.01 per article in 2005-2014. The statistical nature of the method used may have obscured some topics that are now defunct, however, because it will tend to detect more recent topics more easily since they would be represented by more articles in the data set.

The extracted topics are analysed in order of increase in contribution over time.

\subsection{Local development}

This topic has grown fairly steadily during the period analysed from an initial low level. The same is true for the term local on its own, which appears in $14 \%$ of the articles (i.e., title, abstract or keywords) by 2014 . The term community has also grown but peaked in 2002 at $10 \%$ of articles before declining to $6 \%$ in 2014. Local development is closely related to the $16^{\text {th }}$ ranked topic in the 50 topic set community (social community local communities rural groups tourism capital based village development collective networks eco- nomic group people action trust members) and appears in several other topics. Local is a keyword in the topics state governance (ranked 1), development projects (ranked 9) and environmental management (ranked 13). This suggests a generalised shift towards more local issues in development studies and particularly for state governance, development projects, and environmental management. Since local development splits into multiple topics, it may well be substantially different in each one.

\subsection{Gender}

This topic has grown steadily during the period analysed from an initial low level. Gender is ranked second in the 50 topics set (women gender men empowerment female work article equality male family gendered sex violence relations social sexual feminist based participation). The term gender did not appear in a document analysed until 1984 and then it increased in frequency, until stabilising around 8-9\% from 2008. The term women occurred first earlier, in 1976, and then increased in frequency until stabilising between $6-11 \%$ from 2005. Neither of these terms occurs in any of the other top 50 topics. The terms gender and women are also in a single high ranked topic in both the 100 topics set and the 100 topics unigrams set, suggesting that women and gender form a coherent aspect of development research in the sense that there are not different ways of discussing gender even when it is applied in combination with other topics (since each article has contributions from different topics in the topic modelling approach). This supports a previous claim that the term has become relatively uncontested (Smyth, 2010).

\subsection{Politics}

This topic gradually increased in contribution over time, starting from a moderate initial value. The term politics was first mentioned in 1976 and increased steadily until it was mentioned in $6 \%$ of articles by 2014 . State governance (state governance political institutions article power institutional actors local politics policy relations processes social global role change interests context) is top ranked and conflict is ranked five in the 50 topics set. State politics, democracy and war do not seem to be often acknowledged as important new research areas in development studies, although they clearly reflect important changes in the developing world. One exception is a book arguing that conflict has grown in importance since the late 1990s (MacGinty; Williams, 2009).

\subsection{Environment}

This topic gradually increased in contribution over time, from a low initial value to an eventual moderate value. The term environment increased until 1991, stabilising between 6 and 9\%. It is represented in the 50 topics set by sustainable development (ranked 8) and environmental management (ranked 13). As discussed above, the environment has been recognised as being an important and growing issue since the Rio 1992 conference and so its inclusion as a topic and contribution to development studies research is unsurprising. It is perhaps more surprising that its contribution has not increased substantially since Rio. 


\subsection{Poverty}

This topic decreased until about 1995 before increasing to a higher contribution than originally. The term poverty behaved similarly, occurring in about $12 \%$ of the studied articles by 2014. Poverty (poverty poor reduction rural people pro alleviation social livelihoods bangladesh income paper policy vulnerability areas reducing urban households chronic) is ranked 12 in the 50 topics set. The recent increasing relevance of poverty may reflect the impact of recession and may also partly reflect the trend to focus on human development rather than economic development, although this is not clear from the terms in the topic.

\subsection{Aid}

This topic has increased slightly overall but decreased steadily since about 1990 . Aid is ranked only $22^{\text {nd }}$ in the 50 topics set but the term occurs in the Africa (rank 10) and NGOs (ranked 14) topics. The term microfinance is within the aid topic and has increased in use: first occurring in the data set in 1996 , occurring in $2 \%$ of articles by 2014 . The recent decreasing relevance of aid to research may reflect little changing in the amount of aid given and the sources of aid over the past few decades, even though it is presumably the source of most major development initiatives. It is also possible that the millennium development goals (MDGs) have reduced the need to analyse aid given that much of it now has a relatively well agreed MDG purpose (Brown, 2014).

\subsection{Policy}

This makes the most substantial contribution of all topics but has decreased in importance during the 40 years. The term policy occurred steadily in about a quarter of the data set throughout the time period. The narrower topic economic policy (policy economic reform policies reforms adjustment structural market government economy sector political liberalization state paper growth macroeconomic bank liberalisation) is $39^{\text {th }}$ in the 50 topics set. The term policy also occurs in the top ranked state governance topic. This suggests a decreasing relevance for economic policy in development studies research.

\subsection{Agriculture}

This topic decreased in contribution until stabilising in about 1990. The term food has been in approximately constant use for most of the period, agriculture and agricultural have decreased in use and the term land has not changed. Land rights is ranked 20 in the 50 topics set and farming is ranked 43 , indicating an overall decrease. This suggests that agricultural production has become less important within development studies. It may be that the substantial advances during the Green revolution of an earlier period have made agriculture decline in relative importance as a topic.

\subsection{Firms}

This topic decreased steadily and substantially during the period. The term firm was mentioned approximately constantly at 6\% throughout, however. Industry (industry firms export industrial technology manufacturing productivity production technological industries firm exports innovation paper countries sector level trade developing) is ranked 49 in the 50 topics set, showing that it has the second biggest decrease in contribution. The term firm is also in the $19^{\text {th }}$

Table 1. Topics extracted using the bigram method from articles published in 30 development journals 1975-2014, pre-selected for ten topics. The average contribution per article of each topic is recorded for four decades together with the difference between the last and the first decade.

\begin{tabular}{|c|c|c|c|c|c|c|}
\hline $\begin{array}{l}\text { Topic name } \\
\text { (weight) }\end{array}$ & 75-84 & $85-94$ & 95-04 & 05-14 & $\begin{array}{l}\text { Last- } \\
\text { first }\end{array}$ & Keywords associated with the topic \\
\hline $\begin{array}{l}\text { Local develop- } \\
\text { ment }(0.15)\end{array}$ & 0.04 & 0.06 & 0.10 & 0.11 & 0.07 & $\begin{array}{l}\text { Development local social community article ngos participation project } \\
\text { government based research governance programme society public projects } \\
\text { management information participatory }\end{array}$ \\
\hline Gender (0.08) & 0.02 & 0.03 & 0.05 & 0.07 & 0.05 & $\begin{array}{l}\text { Women gender health education children child school aids men hiv work care } \\
\text { female social family study article rights mortality }\end{array}$ \\
\hline Politics (0.18) & 0.10 & 0.10 & 0.12 & 0.13 & 0.03 & $\begin{array}{l}\text { Political state article conflict social politics power economic war democracy } \\
\text { post society rights states relations civil democratic violence world }\end{array}$ \\
\hline Environment (0.09) & 0.03 & 0.05 & 0.05 & 0.06 & 0.03 & $\begin{array}{l}\text { Environmental water management urban resource climate sustainable natural } \\
\text { resources forest conservation development change environment local energy } \\
\text { tourism areas sustainability }\end{array}$ \\
\hline Poverty (0.19) & 0.12 & 0.09 & 0.11 & 0.14 & 0.02 & $\begin{array}{l}\text { Poverty income data household rural households inequality migration results } \\
\text { evidence labor paper poor urban employment analysis level survey wage }\end{array}$ \\
\hline Aid (0.15) & 0.07 & 0.10 & 0.10 & 0.08 & 0.01 & $\begin{array}{l}\text { Aid financial public countries credit private sector government bank reform } \\
\text { debt paper policy developing institutions tax services microfinance market }\end{array}$ \\
\hline Policy (0.36) & 0.20 & 0.20 & 0.20 & 0.18 & -0.01 & $\begin{array}{l}\text { Development policy economic africa article social world countries paper } \\
\text { poverty global international research south policies issues african approach } \\
\text { analysis }\end{array}$ \\
\hline Agriculture (0.09) & 0.08 & 0.07 & 0.05 & 0.05 & -0.03 & $\begin{array}{l}\text { Land food agricultural rural production farmers agriculture farm market mar- } \\
\text { kets labour security agrarian small farming reform scale study crop }\end{array}$ \\
\hline Firms (0.13) & 0.13 & 0.11 & 0.08 & 0.08 & -0.06 & $\begin{array}{l}\text { Firms china trade countries industry technology foreign industrial growth } \\
\text { investment sector market manufacturing paper developing productivity } \\
\text { export firm economic }\end{array}$ \\
\hline Growth (0.16) & 0.19 & 0.17 & 0.12 & 0.09 & -0.10 & $\begin{array}{l}\text { Growth countries trade economic model rate paper capital exchange policy } \\
\text { effects results price economy real financial investment market developing }\end{array}$ \\
\hline
\end{tabular}




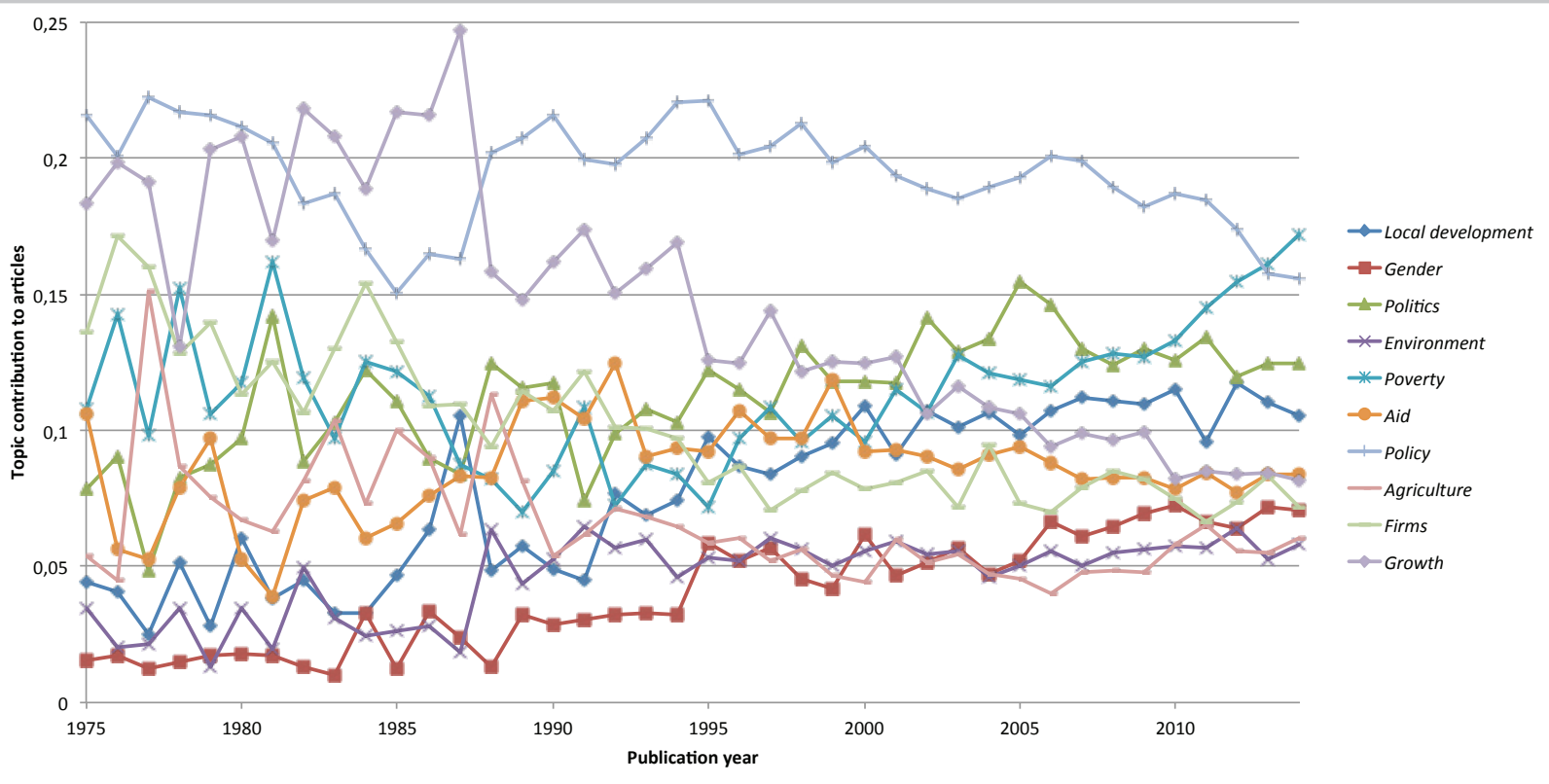

Figure 1. Contributions of the topics extracted from articles in 30 development journals 1975-2014, preselected for ten topics, and using the bigram method. The jaggedness of the lines towards the left of the graph reflect smaller amounts of data rather than underlying instability.

ranked financial sector topic and this may reflect less interest in small firms within development studies in comparison to multinationals due to globalisation.

\subsection{Growth}

This topic decreased dramatically from 1987 and the term growth decreased steadily from 1981 (28\% of articles in the data set included it) to 2014 (12\%). It is ranked 37 in the 50 topics set and is part of the topics income inequality (ranked 36) and economic policy (ranked 39). The reduced focus on economic growth may reflect the discrediting of the economic stages of growth theory and the emergence of globalisation.

\section{Other topics}

Some of the topics increasing or decreasing most over time within the 50 and 100 topics sets do not fit naturally within any of the ten topics reported above. These are discussed here, omitting stylistic topics, methods topics and most topics focusing on one country or region.

7.1. Social development (development social approach theory article practice research studies analysis approaches concept paper economics understanding based discourse argues economic policy) is ranked 3 in the 50 topics set, with a contribution increase from 0.02 per article in 1975-1984 to 0.03 in 2005-2014. This may relate to the human development approach of the UNDP discussed above.

7.2. Education (education children child school schooling mortality educational age fertility health schools primary family status girls household life rates outcomes) is ranked 4 in the 50 topics set, with a contribution increase from 0.01 per article in 1975-1984 to 0.02 in 2005-2014. This may also relate to the UNDP human development approach and the millennium development goals (MDGs).
7.3. Household (household households rural income risk consumption ethiopia data survey shocks farm activities assets asset wealth access expenditure evidence study) is ranked 5 in the 50 topics set, with a contribution increase from 0.01 per article in 1975-1984 to 0.02 in 2005-2014. This is a more methodological topic relating to the increasing tendency to survey households for wealth-related information and risks (see: Heltberg; Oviedo; Talukdar, 2015). The term household(s) occurred in 1\% of articles in 1975 and increased linearly to $15 \%$ in 2014 , co-occurring most with the term survey (30\% of articles containing household(s) also contained survey).

7.4. Human rights (rights social society civil human participation movement movements political citizenship article people brazil justice action public citizens groups street) is ranked 7 in the 50 topics set, with a contribution increase from 0.00 per article in 1975-1984 to 0.01 in 2005-2014. This seems to be more focused on specific human rights issues that Sen's rights-based approach to development and does not seem to be recognised in histories of development studies.

7.5. Africa (africa south african saharan aids hiv north southern apartheid west region economic countries continent policy ssa black paper natal) is ranked 10 in the 50 topics set, with a contribution increase from 0.00 per article in 1975-1984 to 0.01 in 2005-2014. The African continent seems to have become of increasing importance to development studies, partially due to the AIDS epidemic.

7.6. Corruption (corruption information research knowledge technology communication media technologies ict internet university science mobile international icts policy public scientific corrupt) is ranked 21 in the 50 topics set, with a contribution increase from 0.00 per article in 1975-1984 to 0.01 in 2005-2014. This is a recognised issue within development studies (Harrison, 2010). 
7.7. Globalisation (global international world globalization states united globalisation nations cooperation national system emerging integration south major regional economy transnational order) is ranked 26 in the 100 topics unigrams set, with a contribution increase from 0.00 per article in 1975-1984 to 0.01 in 2005-2014. The terms globalisation or globalization are first mentioned in 1987, peak 2000-2004 at $5 \%$ and then decline to $2 \%$ of all articles ( 753 papers overall, $2.8 \%)$. This concept has therefore decreased in importance recently, perhaps becoming part of the accepted economic background rather than a topic of live discussion.

7.8. Food security (food security social protection famine safety insecurity nutrition pension system programmes consumption sovereignty public hunger policy graduation welfare production) is ranked 28 in the 50 topics set, with a contribution increase from 0.00 per article in 1975-1984 to 0.01 in 2005-2014. This encompasses the social protection concept mentioned above but is mainly focused on food.

7.9. Economic theory (world theory neo discourse neoliberal western liberal post political social neoliberalism contemporary critique modern cultural ideas historical moral culture) is ranked 35 in the 100 topics unigrams set, with a contribution stable at 0.01 per article.

7.10. Social capital. Although this is not a topic on its own in any of the topic models, it is an important part of closely related topics. From the 50 topics set, it is part of the $16^{\text {th }}$ ranked community (social community local communities rural groups tourism capital based village development collective networks economic group people action trust members), contributing a constant 0.01 per article throughout 1975-2014. The only other topic containing both of the terms is class (labour agrarian production peasant class capitalist relations capitalism rural author accumulation peasants agriculture economy social capital peasantry structure state) in the 100 unigrams set, which is probably not relevant. The phrase social capital was first mentioned in 1996, occurred in about 1.5\% of articles from 1998 to 2008 and then decreased to about $1 \%$ for the remaining years.

7.11. Exchange rates (exchange rate inflation real monetary financial rates policy money countries macroeconomic price currency run interest paper shocks fiscal volatility) is ranked 44 in the 50 topics set, with a contribution decrease from 0.03 per article in 1975-1984 to 0.01 in 2005-2014. This perhaps reflects less interest in individual national economies and more interest in both globalisation and local development.

\section{Missing development issues}

Some important development studies topics have not been mentioned above. These were searched for in the original data using keyword searches to identify their trends in prevalence.

- BRIC/BRICS. These are first mentioned in 2012 and are only in 23 papers $(0.1 \%)$.

- Dependency theory. This is not a topic in any of the sets analysed but the term dependency occurs within one unigram topic (ranked 65): Brazil (brazil brazilian amazon biofuels deforestation frontier paulo de rio production su- garcane region expansion biofuel amazonia lula ethanol northeast dependency).

- The basic needs approach. The phrase basic needs occurs in none of the articles in the data set.

- Postdevelopment. Expressed through the terms post-development, post development, or postdevelopment, this concept occurred in a steady $0.2 \%$ of articles from 1999 onwards.

- New institutional economics. The phrase institutional economics occurs in none of the articles in the data set.

The topic modelling approach has confirmed the presence and increasing or decreasing nature of the most important concepts within development studies

\section{Limitations and conclusions}

The method used here has the limitation that it is based only on published refereed academic journal articles and much development studies research is in monographs, edited volumes and research reports. In addition, the methods use only the terms in the title, keywords and abstracts of these articles and so may overlook issues that are frequently discussed in the body of papers, such as methodological details and complex issues. Moreover, the statistical modelling approach assumes that the topics discussed are represented in the words used and that the individual topics are constant over time except in the extent to which they are discussed. The method may be weakened by the use of near synonyms that change in popularity over time, such as underdeveloped, developing, third world and global South. The topics are also not completely impartial since they need human interpretation to give them a name and to put them in the context of development studies history, as well as for the initial selection of journals to process. Finally, the data is biased towards topics that are present in the latter part of the time period in which Scopus has much higher coverage. In summary, the results should not be taken as accurate descriptions of trends in development studies but as a partially flawed perspective on them. Ideally, the topic modelling results would be validated through comparisons with external sources of evidence but this does not seem to be possible in this case.

The topic modelling approach has confirmed the presence and increasing or decreasing nature of the most important concepts within development studies, as identified within the literature review, with the exception of the $B R I C / S$, dependency theory, the basic needs approach, postdevelopment and new institutional economics. The topics that do not align naturally with identified development studies trends can give a new perspective on the field.

In answer to the first research question, a range of economics-related issues have declined in interest within development studies, including firms, economic growth, exchange rates, and economic theories. Some non-economic topics have also declined in importance, however, including agri- 
culture. Overall, economic theory and economics in general seem to have become much less important within development studies since the 1970s.

In answer to the second research question, there have been increases in interest in the topics of education, household surveys, human rights and Africa. None of these are directly related to economics and the first three suggest a focus on outcomes for individuals.

The results give a relatively impartial and novel perspective on the history of development studies, providing evidence of the decline of the importance of economics within the field. The broader results can also be cross-referenced against more theoretical approaches or interpretations in order to give a more complete understanding. This should help development studies researchers to situate their own studies within the field and new researchers to understand the field as a whole. The results can perhaps also give knowledge about the topics that are actually researched, irrespective of the popularity of theories or ideas at particular points in time, for example as reflected in popular books and course syllabi. This may help active researchers to understand the relationship between popular ideas and research practice.

\section{References}

Alfini, Naomi; Chambers, Robert (2010). "Words count: taking a count of the changing language of British aid". In: Cornwall, A.; Eade, D.; (eds). Deconstructing development discourse: Buzzwords and fuzzwords, Rugby, UK: Practical Action Publishing, pp. 29-43.

http://www.guystanding.com/files/documents/Deconstructingdevelopment-buzzwords.pdf

Arndt, Heinz W. (1981). "Economic development: A semantic history". Economic development and cultural change, v. 29 n. 3, pp. 457-466.

http://www.urbanjustice.net/courses/sides2015/readings/ week3/class5/Arndt1.pdf

Bebbington, Anthony; Foo, Katherine E. (2014). "Social capital and development. In V. Desai; R. B. Potter (eds.). The companion to development studies ( $3^{\text {rd }}$ ed.). London, UK: Routledge, pp. 235-241. ISBN: 9781444167245

Bindura-Mutangadura, Gladys (2001). “Morbidity and mortality in Zimbabwe's urban areas: policy implications for social protection". Journal of social development in Africa, v. 16 n. 1 , pp. 5-24.

http://dx.doi.org/10.4314/jsda.v16i1.23864

Blei, David M.; Ng, Andrew Y.; Jordan, Michael I. (2003). "Latent Dirichlet allocation". Journal of machine learning research, v. 3, pp. 993-1022.

https://www.cs.princeton.edu/ blei/papers/BleiNgJordan2003. $p d f$

http://dl.acm.org/citation.cfm?id=944937

Braam, Robert R.; Moed, Henk F.; Van Raan, Anthony F. J. (1991). "Mapping of science by combined co-citation and word analysis, I. Structural aspects". Journal of the American Society for Information Science, v. 42 n. 4, pp. 233-251. http://www.cwts.nl/tvr/documents/avr-cocit-word-i.pdf

Briggs, John (2014). “Indigenous knowledge and develo- pment". In V. Desai; R. B. Potter (eds.). The companion to development studies ( $3^{\text {rd }}$ ed.). London, UK: Routledge, pp. 199-204. ISBN: 9781444167245

Brown, Stephen (2014). "Foreign aid in a changing world". In V. Desai; R. B. Potter (eds.). The companion to development studies ( $3^{\text {rd }}$ ed.). London, UK: Routledge, pp. 762-767. ISBN: 9781444167245

Cassiolato, José-Eduardo (2014). "BRICS and development". In V. Desai; R. B. Potter (eds.). The companion to development studies ( ${ }^{\text {rd }}$ ed.). London, UK: Routledge, pp. 73-77. ISBN: 9781444167245

Conway, Gordon (1998). The doubly green revolution: Food for all in the twenty-first century. New York, NY: Cornell University Press. ISBN: 0801486106

Cornwall, Andrea (2010). "Introductory overview buzzwords and fuzzwords: Deconstructing development discourse". In: Cornwall, A.; Eade, D. (eds) Deconstructing development discourse: Buzzwords and fuzzwords, Rugby, UK: Practical Action Publishing, pp. 1-18.

http://www.guystanding.com/files/documents/ Deconstructing-development-buzzwords.pdf

Craggs, Ruth (2014). "Development in a global-historical context". In V. Desai; R. B. Potter (eds.). The companion to development studies ( $3^{\text {rd }}$ ed.). London, UK: Routledge, $\mathrm{pp}$. 5-9. ISBN: 9781444167245

Desai, Vandana; Potter, Rob B. (2014). "Editorial introduction". In V. Desai; R. B. Potter (eds.). The companion to development studies ( $3^{\text {rd }}$ ed.). London, UK: Routledge, pp. 1-3. ISBN: 9781444167245

Ding, Ying; Chowdhury, Gobinda G.; Foo, Schubert (2001). "Bibliometric cartography of information retrieval research by using co-word analysis". Information processing; management, v. 37 n. 6, pp. 817-842.

https://pure.strath.ac.uk/portal/files/107338/strathprints002619.pdf

http://dx.doi.org/10.1016/S0306-4573(00)00051-0

Dodds, Klaus (2014). "The Third World, developing countries, the South, emerging markets and rising powers". In V. Desai; R. B. Potter (eds.). The companion to development studies ( $3^{\text {rd }}$ ed.). London, UK: Routledge, pp. 10-15. ISBN: 9781444167245

Elliott, Jennifer A. (2014). "Development and social welfare/human rights". In V. Desai; R. B. Potter (eds.). The companion to development studies ( $3^{\text {rd }}$ ed.). London, UK: Routledge, pp. 28-33. ISBN: 9781444167245

Escobar, Arturo (1992). "Imagining a post-development era? Critical thought, development and social movements". Social text, n. 31/32, pp. 20-56.

http://www.jstor.org/stable/466217

Griffiths, Thomas L.; Steyvers, Mark (2004). "Finding scientific topics". Proceedings of the National Academy of Science, v. 101 (suppl. 1), pp. 5228-5235.

http://www.pnas.org/content/101/suppl_1/5228.full.pdf

Haddad, Lawrence (2007). "Reinventing development research: Listening to the IDS40 roundtables". IDS Bulletin, v. 
38 n. 2, pp. 1-13.

http://dx.doi.org/10.1111/j.1759-5436.2007.tb00343.x

Harrison, Elizabeth (2010). "Corruption". In: Cornwall, A.; Eade, D.; (eds). Deconstructing development discourse: Buzzwords and fuzzwords, Rugby, UK: Practical Action Publishing, pp. 257-264.

http://www.guystanding.com/files/documents/Deconstructingdevelopment-buzzwords.pdf

He, Qin (1999). "Knowledge discovery through co-word analysis". Library trends, v. 48 n. 1, pp. 133-159.

https://www.ideals.illinois.edu/bitstream/handle/2142/8267/ librarytrendsv48i1i_opt.pdf?sequ

Heltberg, Rasmus; Oviedo, Ana-María; Talukdar, Faiyaz (2015). "What do household surveys really tell us about risk, shocks, and risk management in the developing world?". The journal of development studies, v. 51 n. 3, pp. 209-225 http://dx.doi.org/10.1080/00220388.2014.959934

Herod, Andrew (2014). "Globalisation: An overview". In V. Desai; R. B. Potter (eds.). The companion to development studies ( $3^{\text {rd }}$ ed.). London, UK: Routledge, pp. 245-251. ISBN: 9781444167245

Jolly, Richard (2005). "The UN and development thinking and practice". Forum for development studies, v. 32 n. 1, pp. 49-73.

http://www.unhistory.org/reviews/FDS_Jolly.pdf

Kaldor, Nicholas (1985). The scourge of monetarism ( $2^{\text {nd }}$ ed.). Oxford, UK: Oxford University Press. ISBN: 9780198772484

Khoo, Su-ming (2015). Development studies. International encyclopedia of the social and behavioral sciences ( $2^{\text {nd }}$ ed.). Oxford, UK: Elsevier. ISBN: 9780080970875

Knutsson, Beniamin (2009). "The intellectual history of development - towards a widening potential repertoire". Perspectives, v. 13, April, pp. 2-46.

http://www.gu.se/digitalAssets/1272/1272997_ Perspectives_13.pdf

Lepenies, Philipp (2014). "New institutional economics and development". In V. Desai; R. B. Potter (eds.). The companion to development studies ( $3^{\text {rd }}$ ed.). London, UK: Routledge, pp. 51-55. ISBN: 9781444167245

Lewis, W. Arthur (1978). Theories of economic growth. London: Allen; Unwin. ISBN: 9780043300541

Leydesdorff, Loet (1997). "Why words and co-words cannot map the development of the sciences". Journal of the American Society for Information Science, v. 48, n. 5, pp. 418-427. http://www.leydesdorff.net/cowords

MacGinty, Roger; Williams, Andrew (2009). Conflict and development. Abingdon, UK: Routledge. ISBN: 9780415399371

McCallum, Andrew-Kachites (2002). Mallet: A machine learning for language toolkit.

http://mallet.cs.umass.edu

McMichael, Philip (2012). Development and social change: A global perspective ( $5^{\text {th }}$ ed.). Thousand Oaks, CA: Sage Publications. ISBN: 9781412992077
Mohan, Giles (2014). "Participatory development". In V. Desai; R. B. Potter (eds.). The companion to development studies ( $3^{\text {rd }}$ ed.). London, UK: Routledge, pp. 205-212. ISBN: 9781444167245

Nustad, Knut G. (2001). "Development: The devil we know?". Third World quarterly, v. 22 n. 4, pp. 479-489. http://www.jstor.org/stable/3993352

Pearson, Ruth (2005). "The rise of gender and development". In Kothari, U. (ed.). A radical history of development studies: Individuals, institutions and ideologies. London: Zed Books Ltd., pp. 157-179. ISBN: 9781842775240

Potter, Robert B. (2014a). "The nature of development studies". In V. Desai; R. B. Potter (eds.). The companion to development studies (3 ${ }^{\text {rd }}$ ed.). London, UK: Routledge, pp. 16-20. ISBN: 9781444167245

Potter, Robert B. (2014b). "Theories, strategies and ideologies of development studies: An overview". In V. Desai; R. B. Potter (eds.). The companion to development studies ( $3^{\text {rd }}$ ed.). London, UK: Routledge, pp. 137-143. ISBN: 978 1444167245

Potter, Robert B.; Conway, Dennis (2011). "Development". In: Agnew, J. A. and Livingstone, D. N. (eds.) The SAGE handbook of geographical knowledge. London: Sage, pp. 595610. ISBN: 9781412910811

Preston, Peter W. (1996). Development theory: An introduction. Oxford: Blackwell. ISBN: 9780631195542

Redclift, Michael (2014). "Sustainable development". In V. Desai; R. B. Potter (eds.). The companion to development studies ( $3^{\text {rd }}$ ed.). London, UK: Routledge, pp. 481-485. ISBN: 9781444167245

Rigg, Jonathan (2014). "The millennium development goals". In V. Desai; R. B. Potter (eds.). The companion to development studies ( $3^{\text {rd }}$ ed.). London, UK: Routledge, pp. 6773. ISBN: 9781444167245

Rist, Gilbert (2014). The history of development: From western origins to global faith. London: Zed Books Ltd. ISBN: 9781848131897

Rostow, Walt-Whitman (1960). The stages of economic growth: A non-communist manifesto. Cambridge: Cambridge University Press. ISBN: 9780521409285

Schuurman, Frans J. (2009). "Critical development theory: moving out of the twilight zone". Third World quarterly, v. 30 n. 5, pp. 831-848.

http://dx.doi.org/10.1080/01436590902959024

Schuurman, Frans J. (2014). "The impasse in development studies". In V. Desai; R. B. Potter (eds.). The companion to development studies ( $3^{\text {rd }}$ ed.). London, UK: Routledge, pp. 21-24. ISBN: 9781444167245

Sen, Amartya (1983). "Development: Which way now?". The economic journal, v. 93 n. 372, pp. 745-762. http://www.jstor.org/stable/2232744

Sen, Amartya (1999). Development as freedom. Oxford, UK: Oxford University Press. ISBN: 9780192893307 
Sidaway, James D. (2014). "Post-development". In V. Desai; R. B. Potter (eds.). The companion to development studies ( $3^{\text {rd }}$ ed.). London, UK: Routledge, pp. 227-234. ISBN: 9781444167245

Smyth, Ines (2010). "Talking of gender: words and meanings in development organisations". In: Cornwall, A.; Eade, D.; (eds.). Deconstructing development discourse: Buzzwords and fuzzwords, Rugby, UK: Practical Action Publishing, pp. 143-152.

http://www.guystanding.com/files/documents/Deconstructingdevelopment-buzzwords.pdf

Standing, Guy (2010). "Social protection". In: Cornwall, A.; Eade, D.; (eds.). Deconstructing development discourse: Buzzwords and fuzzwords. Rugby, UK: Practical Action Publishing, pp. 53-67.

http://www.guystanding.com/files/documents/Deconstructingdevelopment-buzzwords.pdf

Sumner, Andy; Tribe, Michael A. (2008a). "What could development studies be?". Development in practice, v. $18, \mathrm{n}$. 6, pp. 755-766.

http://dx.doi.org/10.1080/09614520802386603

Sumner, Andy; Tribe, Michael A. (2008b). International development studies: Theories and methods in research and practice. London, UK: Sage. ISBN: 9781412929455

Tang, Jian; Meng, Zhaoshi; Nguyen, Xuanlong; Mei, Qiaozhu; Zhang, Ming (2014). "Understanding the limiting factors of topic modeling via posterior contraction analysis". In Proceedings of the $31^{\text {st }}$ Intl conf on machine learning, pp. 190-198. http://jm/r.org/proceedings/papers/v32/tang14.pdf

Thelwall, Mike; Maflahi, Nabeil (2015). "How important is computing technology for library and information science research?". Library and information science research, v. 37, n. 1, pp. 42-50.

http://www.scit.wlv.ac.uk/ cm1993/papers/Computers/nLISPreprint. $p d f$

Thirlwall, Anthony-Philip (2011). Economics of development: Theory and evidence ( $9^{\text {th }}$ ed.). Basingstoke, UK: Palgrave Macmillan. ISBN: 9780230222298

United Nations (1961). "United Nations development decade: A programme for international economic cooperation". General Assembly resolution 1710 (XVI).

http://www.un.org/documents/ga/res/16/ares16.htm

United Nations (1975). What now: The 1975 Dag Hammarskjöld report on development and international cooperation. Uppsala, Sweden: Dag Hammarskjöld Foundation.

United Nations (2000). United Nations millennium declaration. http://www.un.org/millennium/declaration/ares552e.pdf

United Nations Development Programme (1999). Human development report 1999. Oxford, UK: Oxford University Press. http://hdr.undp.org/sites/default/files/reports/260/ hdr_1999_en_nostats.pdf

Wallach, Hanna M. (2006). "Topic modeling: beyond bagof-words". In Procs of the $23^{\text {rd }}$ intl conf on machine learning. New York: ACM Press, pp. 977-984.

http://dirichlet.net/pdf/wallach06topic.pdf
Willis, Katie (2011). Theories and practices of development. New York: Routledge. ISBN: 9780415590716

World Commission on Environment and Development (1987). "Our common future". London: Oxford University Press. http://www.un-documents.net/our-common-future.pdf

Yan, Erjia (2015). "Research dynamics, impact, and dissemination: A topic-level analysis". Journal of the Association for Information Science; Technology, v. 66 n. 11, pp. 2357-2372. http://dx.doi.org/10.1002/asi.23324

\section{Appendix}

Table 2. Journals in the core set and properties of their articles indexed in Scopus 1975-2014

\begin{tabular}{|c|c|c|c|}
\hline Journal & Articles & $\begin{array}{l}\text { First } \\
\text { year }\end{array}$ & $\begin{array}{l}\text { Last } \\
\text { year }\end{array}$ \\
\hline African development review & 471 & 1989 & 2014 \\
\hline Developing economies & 536 & 1978 & 2014 \\
\hline Development and change & 774 & 1996 & 2014 \\
\hline Development in practice & 1,092 & 1992 & 2014 \\
\hline Development policy review & 637 & 1989 & 2014 \\
\hline Development Southern Africa & 955 & 1991 & 2014 \\
\hline $\begin{array}{l}\text { Economic development and cultural } \\
\text { change }\end{array}$ & 515 & 1995 & 2014 \\
\hline $\begin{array}{l}\text { European journal of development } \\
\text { research }\end{array}$ & 635 & 1989 & 2014 \\
\hline Forum for development studies & 339 & 1992 & 2014 \\
\hline Gender and development & 548 & 1995 & 2014 \\
\hline IDS bulletin & 1,339 & 1988 & 2014 \\
\hline Journal of African economies & 596 & 1992 & 2014 \\
\hline Journal of developing societies & 449 & 1985 & 2014 \\
\hline Journal of development economics & 2,420 & 1975 & 2014 \\
\hline Journal of development studies & 1,567 & 1979 & 2014 \\
\hline Journal of environment and development & 346 & 1996 & 2014 \\
\hline Journal of international development & 1,497 & 1989 & 2014 \\
\hline Journal of peasant studies & 756 & 1978 & 2014 \\
\hline Journal of social development in Africa & 327 & 1986 & 2013 \\
\hline Journal of Third World studies & 402 & 1992 & 2013 \\
\hline Oxford development studies & 423 & 1996 & 2014 \\
\hline Regional development dialogue & 665 & 1980 & 2014 \\
\hline Review of African political economy & 694 & 1981 & 2014 \\
\hline Review of development economics & 751 & 1997 & 2014 \\
\hline Savings and development & 402 & 1996 & 2013 \\
\hline $\begin{array}{l}\text { Studies in comparative international } \\
\text { development }\end{array}$ & 451 & 1988 & 2014 \\
\hline Sustainable development & 506 & 1994 & 2014 \\
\hline Third World quarterly & 1,484 & 1980 & 2014 \\
\hline World Bank research observer & 304 & 1986 & 2014 \\
\hline World development & 4,804 & 1975 & 2014 \\
\hline Total & 26,685 & - & - \\
\hline
\end{tabular}

